\title{
In situ measurements of molecular iodine in the marine boundary layer: the link to macroalgae and the implications for $\mathrm{O}_{3}$, IO, OIO and $\mathrm{NO}_{\mathrm{x}}$
}

\author{
R.-J. Huang ${ }^{1}$, K. Seitz ${ }^{2}$, J. Buxmann ${ }^{2}$, D. Pöhler ${ }^{2}$, K. E. Hornsby ${ }^{3}$, L. J. Carpenter ${ }^{3}$, U. Platt ${ }^{2}$, and T. Hoffmann ${ }^{1}$ \\ ${ }^{1}$ Institute of Inorganic and Analytical Chemistry, Johannes Gutenberg-University of Mainz, Duesbergweg 10-14, \\ 55128 Mainz, Germany \\ ${ }^{2}$ Institute of Environmental Physics, University of Heidelberg, Im Neuenheimer Feld 229, 69120 Heidelberg, Germany \\ ${ }^{3}$ Department of Chemistry, University of York, Heslington, York YO10 5DD, UK
}

Received: 9 November 2009 - Published in Atmos. Chem. Phys. Discuss.: 8 January 2010

Revised: 4 May 2010 - Accepted: 18 May 2010 - Published: 26 May 2010

\begin{abstract}
Discrete in situ atmospheric measurements of molecular iodine $\left(\mathrm{I}_{2}\right)$ were carried out at Mace Head and Mweenish Bay on the west coast of Ireland using diffusion denuders in combination with a gas chromatography-mass spectrometry (GC-MS) method. $\mathrm{I}_{2}, \mathrm{IO}$ and $\mathrm{OIO}$ were also measured by long-path differential optical absorption spectroscopy (LP-DOAS). The simultaneous denuder and LPDOAS $\mathrm{I}_{2}$ measurements were well correlated $\left(R^{2}=0.80\right)$ but the denuder method recorded much higher concentrations. This can be attributed to the fact that the in situ measurements were made near to macroalgal sources of $\mathrm{I}_{2}$ in the intertidal zone, whereas the LP-DOAS technique provides distance-averaged mixing ratios of an inhomogeneous distribution along the light-path. The observed mixing ratios of $\mathrm{I}_{2}$ at Mweenish Bay were significantly higher than that at Mace Head, which is consistent with differences in local algal biomass density and algal species composition. Above algal beds, levels of $\mathrm{I}_{2}$ were found to correlate inversely with tidal height and positively with the concentrations of $\mathrm{O}_{3}$ in the surrounding air, indicating a role for $\mathrm{O}_{3}$ in the production of $\mathrm{I}_{2}$ from macroalgae, as has been previously suggested from laboratory studies. However, measurements made $\sim 150 \mathrm{~m}$ away from the algal beds showed a negative correlation between $\mathrm{O}_{3}$ and $\mathrm{I}_{2}$ during both day and night. We interpret these results to indicate that the released $\mathrm{I}_{2}$ can also lead to $\mathrm{O}_{3}$ destruction via the reaction of $\mathrm{O}_{3}$ with $\mathrm{I}$ atoms that are formed by the photolysis of $\mathrm{I}_{2}$ during the day and via the
\end{abstract}

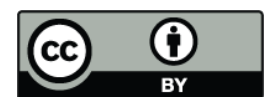

Correspondence to: T. Hoffmann (hoffmant@uni-mainz.de ) reaction of $\mathrm{I}_{2}$ with $\mathrm{NO}_{3}$ radicals at night. The results show that the concentrations of daytime IO are correlated with the mixing ratios of $I_{2}$, and suggest that the local algae sources dominate the inorganic iodine chemistry at Mace Head and Mweenish Bay.

\section{Introduction}

The role of iodine chemistry in ozone depletion events and marine aerosol formation has received considerable attention in the past few years (Saiz-Lopez et al., 2007; Read et al., 2008; Huang et al., 2010; O'Dowd et al., 2002; Vogt et al., 1999; Seitz et al., 2010). The precursors for these iodine-related atmospheric processes have been proposed, from early studies, to be iodocarbons such as $\mathrm{CH}_{3} \mathrm{I}, \mathrm{CH}_{2} \mathrm{I}_{2}$, $\mathrm{CH}_{2} \mathrm{ClI}, \mathrm{CH}_{2} \mathrm{BrI}, \mathrm{C}_{2} \mathrm{H}_{5} \mathrm{I}, \mathrm{C}_{3} \mathrm{H}_{7} \mathrm{I}$, or $\mathrm{C}_{4} \mathrm{H}_{9} \mathrm{I}$ (Carpenter et al., 1999). However, recent field measurements show that molecular iodine $\left(\mathrm{I}_{2}\right)$ is probably the dominant source of atmospheric iodine in certain coastal regions. A maximum $\mathrm{I}_{2}$ mixing ratio of 93 parts per trillion by volume (pptv) at night and of 25 pptv during the day was observed during the North Atlantic Marine Boundary Layer Experiment (NAMBLEX) field campaign at Mace Head, Ireland in summer 2002 using long-path differential optical absorption spectroscopy (LPDOAS) (Saiz-Lopez and Plane, 2004). During daylight, $\mathrm{I}_{2}$ molecules in the atmosphere photolyze to I atoms which then react with $\mathrm{O}_{3}$ to form iodine oxide (IO). A clear anticorrelation between IO and tidal height and a correlation between IO and solar irradiation were also observed at Mace Head (Carpenter et al., 2001; Saiz-Lopez et al., 2006a). The

Published by Copernicus Publications on behalf of the European Geosciences Union. 
self-reaction of IO is thought to result in the formation of higher iodine oxides like OIO or $\mathrm{I}_{2} \mathrm{O}_{4}$ and finally leads to new particle formation (Hoffmann et al., 2001; O'Dowd and Hoffmann, 2005; Pirjola et al., 2005). Also, IO radicals play a key role in a number of other important tropospheric processes, including $\mathrm{NO}_{\mathrm{x}}$ and $\mathrm{HO}_{\mathrm{x}}$ chemistry.

Biogenic emission of $\mathrm{I}_{2}$ by macroalgae has been suggested to be one of the most important processes responsible for the observed tropospheric iodine levels in coastal locations (McFiggans et al., 2004; Pirjola et al., 2005; Palmer et al., 2005). A recent study shows that iodine is accumulated in macroalgae (e.g., Laminaria digitata) in the form of iodide, which can react with $\mathrm{O}_{3}$ when the plants are exposed to the ambient air at low tide, leading to the direct release of $\mathrm{I}_{2}$ into the atmosphere (Küpper et al., 2008). However, the correlations between $\mathrm{I}_{2}$ emissions and algal species are still poorly understood, especially under ambient conditions, so that the impacts of biogenic emission of $\mathrm{I}_{2}$ on tropospheric photochemistry on regional and global scales remain an open question.

Currently, data on ambient $\mathrm{I}_{2}$ are still quite scarce, and most of the measurements have been carried out by longpath differential optical absorption spectroscopy (LP-DOAS) (Saiz-Lopez and Plane, 2004; Saiz-Lopez et al., 2006a; Peters et al., 2005). This technique provides spatial average concentrations along the DOAS light-path (usually several kilometres in length), thus is incapable of resolving inhomogeneous distributions of $\mathrm{I}_{2}$. However, it has been proposed that the spatial variability of the sources of reactive iodine leads to significant spatial variations in the concentrations of iodine species. Thus, the DOAS measurements cannot clearly identify the sources of the iodine species (Peters et al., 2005; von Glasow and Crutzen, 2007). Therefore, "point" in situ measurements of gaseous $\mathrm{I}_{2}$ are highly desirable to better identify the potential source of molecular iodine. A broadband cavity ring-down spectrometer (BBCRDS) was deployed during the NAMBLEX campaign, and the application of this system to point measurements of ambient $\mathrm{I}_{2}$ has been demonstrated (Bitter et al., 2005). Recently, incoherent broadband cavity-enhanced absorption spectroscopy (IBBCEAS) has been developed in the laboratory for gaseous $\mathrm{I}_{2}$ measurements (Vaughan et al., 2008). However, the detection limits of these spectrometric methods are relatively high ( $20 \mathrm{ppt})$, which makes the clear identification of daytime $\mathrm{I}_{2}$ still difficult. In addition, the initial concentrations from direct $\mathrm{I}_{2}$ emissions are not accessible by LP-DOAS method since the light-path runs mostly at a height of several meters above the ground and the rapid photolysis of $I_{2}$ during daytime causes a vertical concentration gradient. However, model studies have predicted that even very low concentrations of $I_{2}$ under daytime conditions could strongly affect the marine atmosphere (Peters et al., 2005).

In this paper, we present the results of a 5-week field campaign carried out at Mace Head and Mweenish Bay located at the West Coast of Ireland in August/September 2007. Ambient $I_{2}$ mixing ratios were measured by a diffu- sion denuder system combined with a gas chromatographymass spectrometry (GC-MS) with precolumn derivatization method and by the DOAS technique for comparison. The correlation between $\mathrm{I}_{2}$ concentrations at different measurement sites, ozone concentrations, tidal height, and occurrence of different algal species were investigated. Also the impact of iodine on nighttime chemistry was studied.

\section{Experimental}

\subsection{Diffusion denuder sampling in combination with GC-MS measurements}

The collection of $\mathrm{I}_{2}$ on diffusion denuder tubes $(6 \mathrm{~mm}$ i.d. $\times 50 \mathrm{~cm}$ length, Huang and Hoffmann, 2009) is based on the rapid formation of inclusion complexes of $\mathrm{I}_{2}$ with the combined coatings $\alpha$-cyclodextrin $(\alpha-\mathrm{CD})$ and iodide $\left(\mathrm{I}^{-}\right)$. To obtain denuders coated uniformly with the coating reagents, nine $0.5 \mathrm{~mL}$ aliquots of coating solution $\left(2.5 \mathrm{mg} \mathrm{mL}^{-1} \alpha\right.$ $\mathrm{CD}$ and trace ${ }^{129} \mathrm{I}^{-}$in methanol) were slowly pipetted into the openings of the brown denuder tube which was held at an angle of about $10^{\circ}$ relative to the horizontal plane. During the coating procedure the tubes were rotated and flushed with nitrogen for drying (flow rate $0.5 \mathrm{~L} \mathrm{~min}^{-1}$ ). Afterward, the coated denuders were sealed with polypropylene (PP) end-caps and stored under refrigeration until sampling. At the sampling site, the denuders were set vertically to eliminate particle deposition due to gravitational settling. The interference iodine species were isolated by coupling a 1,3,5-trimethoxybenzene-coated denuder upstream of the $\alpha$ $\mathrm{CD} / \mathrm{I}^{-}$-coated denuder (Huang and Hoffmann, 2009), and an untreated glass tube of specific length $(15 \mathrm{~cm})$ with the same diameter as the denuder tube was coupled to the denuder inlet, used as a subduction zone to adjust the laminar flow of the sampled air into the denuder. Ambient air was sampled through the denuder system by a membrane pump located downstream of the denuder for $30-180 \mathrm{~min}$ at a flow rate of $500 \mathrm{~mL} \mathrm{~min}^{-1}$. Once the sampling was completed, the open ends of the tubes were again sealed with PP end-caps and kept under refrigeration until subsequent laboratory measurements.

In the laboratory, the samples were eluted with five $2.0 \mathrm{~mL}$-portions of ultrapure water into a $25-\mathrm{mL}$ calibrated flask. Amounts of $500 \mu \mathrm{L}$ of phosphate buffer (pH 6.4), $100 \mu \mathrm{L}$ of $2,4,6$-tribromoaniline $\left(2.5 \mathrm{mg} \mathrm{L}^{-1}\right.$, internal standard), $400 \mu \mathrm{L}$ of sodium 2-iodosobenzoate, and $300 \mu \mathrm{L}$ of $N, N$-dimethylaniline were then added. The solution was diluted to about $23 \mathrm{~mL}$ with ultrapure water and subsequently shaken at room temperature for about $120 \mathrm{~min} .2 .0 \mathrm{~mL}$ of sodium acetate solution $(20 \% \mathrm{~m} / \mathrm{v})$ was then introduced, and the solution was diluted to the mark with ultrapure water. Finally, the solution was extracted with $100 \mu \mathrm{L}$ of cyclohexane. $1.0 \mu \mathrm{L}$ of the solution was injected into a gas chromatography with an ion-trap mass spectrometer (Trace GC/PolarisQ, 
Thermo Finnigan Italia S.p.A., Rodano, Italy). A fusedsilica capillary column $\left(30 \mathrm{~m} \times 0.25 \mathrm{~mm}\right.$ i.d., $d_{f}: 0.25 \mu \mathrm{m}$, Rtx-5MS, Restek Co., Bad Homburg, Germany) was used for chromatographic separation. High-purity helium (99.999\%) was used as a carrier gas at a constant flow of $1.0 \mathrm{~mL} \mathrm{~min}^{-1}$. The temperature of the injector was set to $250^{\circ} \mathrm{C}$ and the transfer line was $300^{\circ} \mathrm{C}$. The temperature of the $\mathrm{GC}$ oven was programmed as follows: initial temperature $50^{\circ} \mathrm{C}$ (hold $3 \mathrm{~min}$ ), $30^{\circ} \mathrm{C} \mathrm{min}^{-1}$ to $220^{\circ} \mathrm{C}$ (hold $3 \mathrm{~min}$ ). The MS was operated in the electron impact (EI) ionization mode with an acceleration energy of $70 \mathrm{eV}$. A solvent delay of $4.5 \mathrm{~min}$ preceded the MS spectra acquisition in the selected ion monitoring (SIM) mode in the following sequence: $4.50-6.00 \mathrm{~min}$, $\mathrm{m} / \mathrm{z}: 77,121 ; 6.00-7.50 \mathrm{~min}, \mathrm{~m} / \mathrm{z}: 119,247 ; 7.50-11.67 \mathrm{~min}$, $m / z: 250,329,331$. The blanks were estimated by measuring the unsampled denuders which were sealed throughout the campaign and were found to be within the ranges of the limit of detection ( $0.17 \mathrm{pptv})$.

\subsection{DOAS measurements}

DOAS is a well established technique to identify and quantify trace gases by their narrow band absorption structures (Platt and Stutz, 2008). In this study, two active LP-DOAS instruments were used (Seitz et al., 2010). A light beam generated by a high pressure Xe-arc lamp (type: XBO500, Osram) was passed through a telescope of $1.5 \mathrm{~m}$ focal length then through the open atmosphere to an array of quartz prism retro-reflectors $(63 \mathrm{~mm}$ diameter each). For the measurements at Mace Head the light-path $(6.8 \mathrm{~km}$, one-way) crossed Roundstone Bay to Roundstone about $10 \mathrm{~m}$ above sea level at high tide, where the reflector (consisting of 76 quartz prisms) was located. At Mweenish Bay, a light-path $(2.0 \mathrm{~km}$, oneway, 39 quartz prisms) was established crossing Mweenish Bay at about $5 \mathrm{~m}$ above sea level at high tide. For both instruments the reflected light was analyzed by a spectrometer (Acton Spectra Pro 300, $f=4.1,1900 \mathrm{gr} \mathrm{mm}^{-1}$ and an Acton Spectra Pro 500, $f=6.9,600 \mathrm{gr} \mathrm{mm}^{-1}$ grating for the measurements at Mace Head and Mweenish Bay, respectively). The detector used was a 1024 pixel photodiode array detector (type: S3904-1024, Hamamatsu). $\mathrm{O}_{3}$ was measured in $320 \pm 40 \mathrm{~nm}, \mathrm{IO}$ in $430 \pm 40 \mathrm{~nm}, \mathrm{I}_{2}$ and $\mathrm{OIO}$ in $550 \pm 40 \mathrm{~nm}$, and $\mathrm{NO}_{3}$ in $630 \pm 40 \mathrm{~nm}$. For the analysis of the LP-DOAS data the software DOASIS (Kraus, 2005) was used to simultaneously fit the different references to the atmospheric spectrum using a non-linear least-squares method (e.g., Stutz and Platt, 1996). In addition, a polynomial was included to account for broad band structures due to scattering in the atmosphere. IO was analyzed in the wavelength range between 416 and $439 \mathrm{~nm}$. The IO cross section (Spietz et al., 2005) as well as references of $\mathrm{NO}_{2}$ (Voigt et al., 2002) and $\mathrm{H}_{2} \mathrm{O}$ (Rothmann et al., 2005) were included in the IO fitting procedure. The evaluation of $\mathrm{I}_{2}$ was performed in the wavelength range 530 to $567 \mathrm{~nm}$ and the cross sections of $\mathrm{I}_{2}$ (Saiz-Lopez et al., 2004), references of OIO (Bloss et al,
2001), $\mathrm{NO}_{2}, \mathrm{O}_{4}$ (Greenblatt et al., 1990) and $\mathrm{H}_{2} \mathrm{O}$ were considered during the fit. $\mathrm{O}_{3}$ was analyzed between 315 and $342.5 \mathrm{~nm}$ (Mweenish Bay) and 332.5 and $343.75 \mathrm{~nm}$ (Mace Head) and the cross sections of $\mathrm{O}_{3}$ (Voigt et al., 2001), $\mathrm{BrO}$ (Wilmouth et al., 1999), $\mathrm{SO}_{2}$ (Vandaele et al., 1994), HCHO (Meller and Moortgat, 2000), $\mathrm{NO}_{2}, \mathrm{O}_{4}$ and HONO (Stutz et al., 2000) were included in the fitting procedure. $\mathrm{NO}_{3}$ was analyzed between 618 and $626 \mathrm{~nm}$ and 657 and $664 \mathrm{~nm}$ and fitted using $\mathrm{NO}_{3}$ (Yokelson et al., 1994) and $\mathrm{H}_{2} \mathrm{O}$ cross sections.

\subsection{Online GC-MS measurements}

$\mathrm{CH}_{3} \mathrm{I}, \mathrm{C}_{2} \mathrm{H}_{5} \mathrm{I}, \mathrm{CH}_{2} \mathrm{BrI}, \mathrm{CH}_{2} \mathrm{ICl}$ and $\mathrm{CH}_{2} \mathrm{I}_{2}$ were analysed automatically from $3 \mathrm{~L}$ of dried air using a Perkin Elmer (USA) Turbomass GC-MS system connected to a Perkin Elmer Automated Thermal Desorption unit (ATD). Air samples were measured every 45 min during 5 days of measurement between the 29 August and the 11 September 2007. Analytes were trapped onto a 3-stage carbon-based adsorbent micro trap (Air monitoring trap, Perkin Elmer, UK) held at $-30^{\circ} \mathrm{C}$. The micro trap was then flash heated to $360^{\circ} \mathrm{C}$, injected onto a $60 \mathrm{~m}$ DB5 GC column (Supelco), then analysed by the MS in single ion mode. The GC-MS was calibrated against a gas standard prepared in-house containing low-pptv mixing ratios of the target halocarbons in zero grade nitrogen (BOC, UK) at 100 bar in an Aculife cylinder (10 L, CK Gases). This gas standard was quantified in our laboratory against a permeation tube system (Wevill and Carpenter, 2004) immediately after the campaign. The method is discussed in more detail in Hornsby et al. (2009).

\subsection{Sampling sites}

The denuder sampling systems and LP-DOAS instruments were positioned at the Mace Head Atmospheric Research Station $\left(53.32^{\circ} \mathrm{N}, 9.90^{\circ} \mathrm{W}\right)$ and at Mweenish Bay $\left(53.31^{\circ} \mathrm{N}\right.$, $9.83^{\circ} \mathrm{W}$ ) (see Fig. 1). Also, at Mace Head, in situ measurements of reactive halocarbons were carried out by the online GC-MS system. The Mace Head site is well known for atmospheric events with regard to iodine chemistry. A detailed description of this measurement site can be found elsewhere (Carpenter et al., 2001). Mweenish Bay is located about $7 \mathrm{~km}$ southeast of the Mace Head research station in an area of large seaweed beds. The algae species present differ from those at Mace Head, with the brown algae Ascophyllum nodosum and Fucus vesiculosus being dominant (Irish Seaweed Centre, 2001). In addition, Mweenish Bay has a higher seaweed density. Denuder sampling was carried out in the intertidal zone at Mweenish Bay-II for 30 consecutive days (6 August-4 September, 2007) and at Mace Head for 6 consecutive days (28 August-2 September, 2007). To explore the concentration levels of $\mathrm{I}_{2}$ from direct biogenic emissions, several samples were taken by denuder during low tide in the central zone of algal beds (Mweenish Bay-I). The 


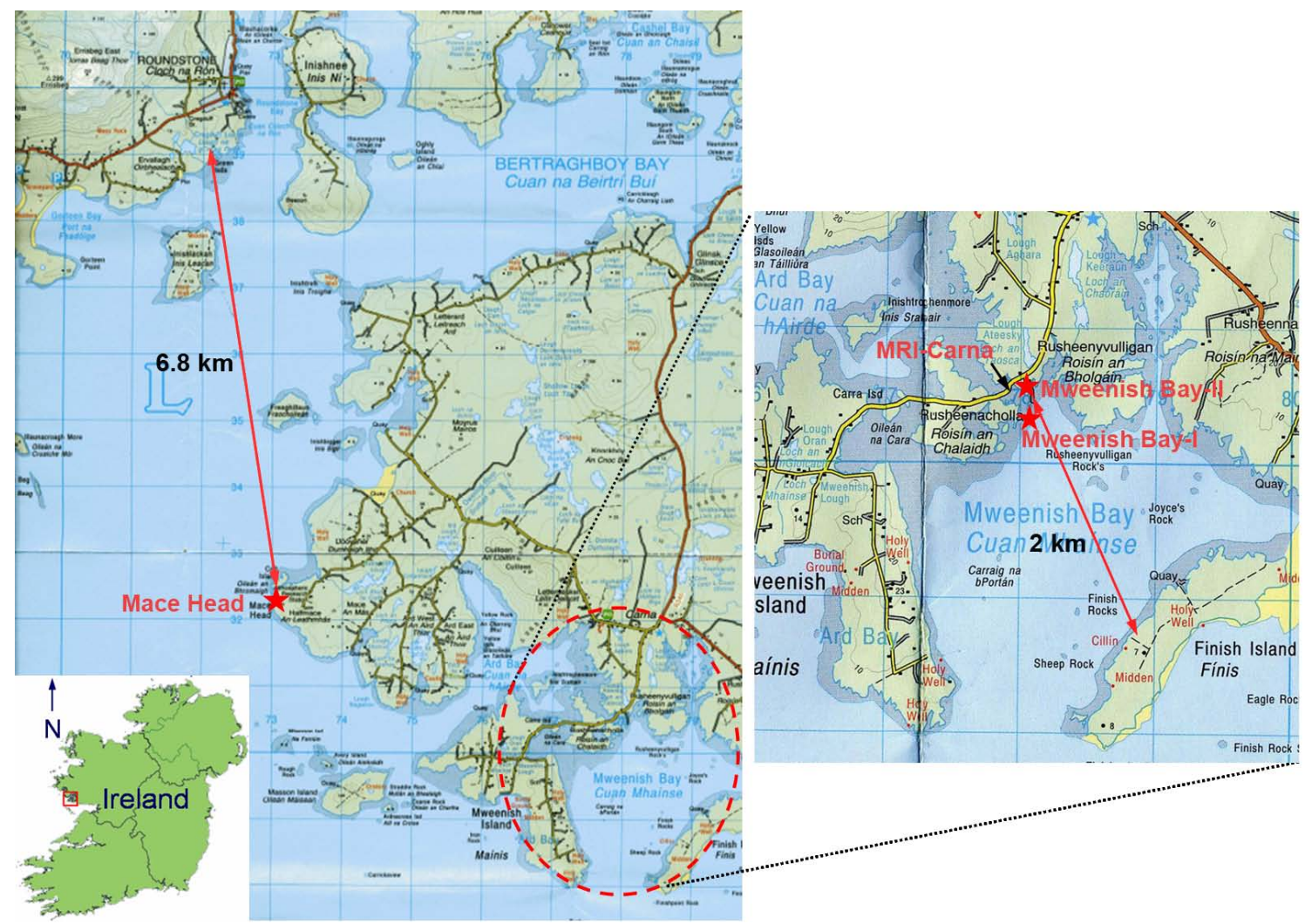

Fig. 1. The denuder sampling sites ( $\star$ ) and the light paths of the LP-DOAS measurements at Mace Head and Mweenish Bay, Ireland.

distance between Mweenish Bay-I and Mweenish Bay-II is about $100-150 \mathrm{~m}$.

\section{Results and discussion}

\subsection{Iodine emissions from macroalgae}

Although laboratory-based studies have observed the direct emissions of $\mathrm{I}_{2}$ from macroalgae (e.g., Laminaria) (Sellegri et al., 2005; Küpper et al., 2008; Dixneuf et al., 2009), the levels of $\mathrm{I}_{2}$ emissions under atmospheric conditions have not been clarified so far. To address this question we used diffusion denuders which can provide "single-point" in situ measurements of $I_{2}$ to collect samples at the central zone of algal beds (Mweenish Bay-I) during low tide. Since $I_{2}$ is rapidly photolyzed to iodine atoms during daytime, the denuder tubes were set up directly above the algal beds with a very short vertical distance of around $5 \mathrm{~cm}$ between the seaweed and the denuder inlet to minimize the potential influence of photolysis. Figure 2a shows the results of 5-day measurements within a period of 21 days, at a fixed sampling site. The mixing ratios of $\mathrm{I}_{2}$ were observed to fluctuate with a range between 110 and 302 ppt. This fluctuation could be attributed to algae themselves and the surrounding atmosphere. Küpper et al. (1998) report that young plantlets of seaweed have a larger capacity of iodine uptake than adult plants. Thus, within these 21 days the changes of physiological conditions of algae can lead to the differences of iodine level accumulated in the seaweed and thereby the emission level of $\mathrm{I}_{2}$ into the air. Other factors such as solar radiation, temperature, and ozone concentration may also have contributed to the observed fluctuation of $\mathrm{I}_{2}$ emission. A plot of the $\mathrm{I}_{2}$ mixing ratio observed at Mweenish Bay-I against the measured $\mathrm{O}_{3}$ (Fig. 2b) shows that the emissions of $\mathrm{I}_{2}$ increase with increasing $\mathrm{O}_{3}$ mixing ratio. This finding (although the data set is very limited) is in close agreement with the result from a chamber experiment (Palmer et al., 2005) as well as the recently suggested mechanism in which $\mathrm{I}_{2}$ emissions are supposed to be regulated by the ozone-scavenging reaction of the accumulated iodide on the algae surfaces (Küpper et al., 2008).

Given the short atmospheric lifetime of $I_{2}$ and the dilution effect during air transport (Saiz-Lopez et al., 2004, 2006b; Palmer et al., 2005), the $I_{2}$ mixing ratio downwind of the seaweed beds could be lower. As expected, the mixing ratios of $\mathrm{I}_{2}$ observed at Mweenish Bay-II (i.e., further far away from the seaweed beds) decreased significantly compared to the enhanced levels observed at Mweenish Bay-I (Fig. 2a). These comparison results were associated with northwesterly/southwesterly winds which passed over the algal beds with speeds $<7.7 \mathrm{~m} \mathrm{~s}^{-1}$. When the wind came from 

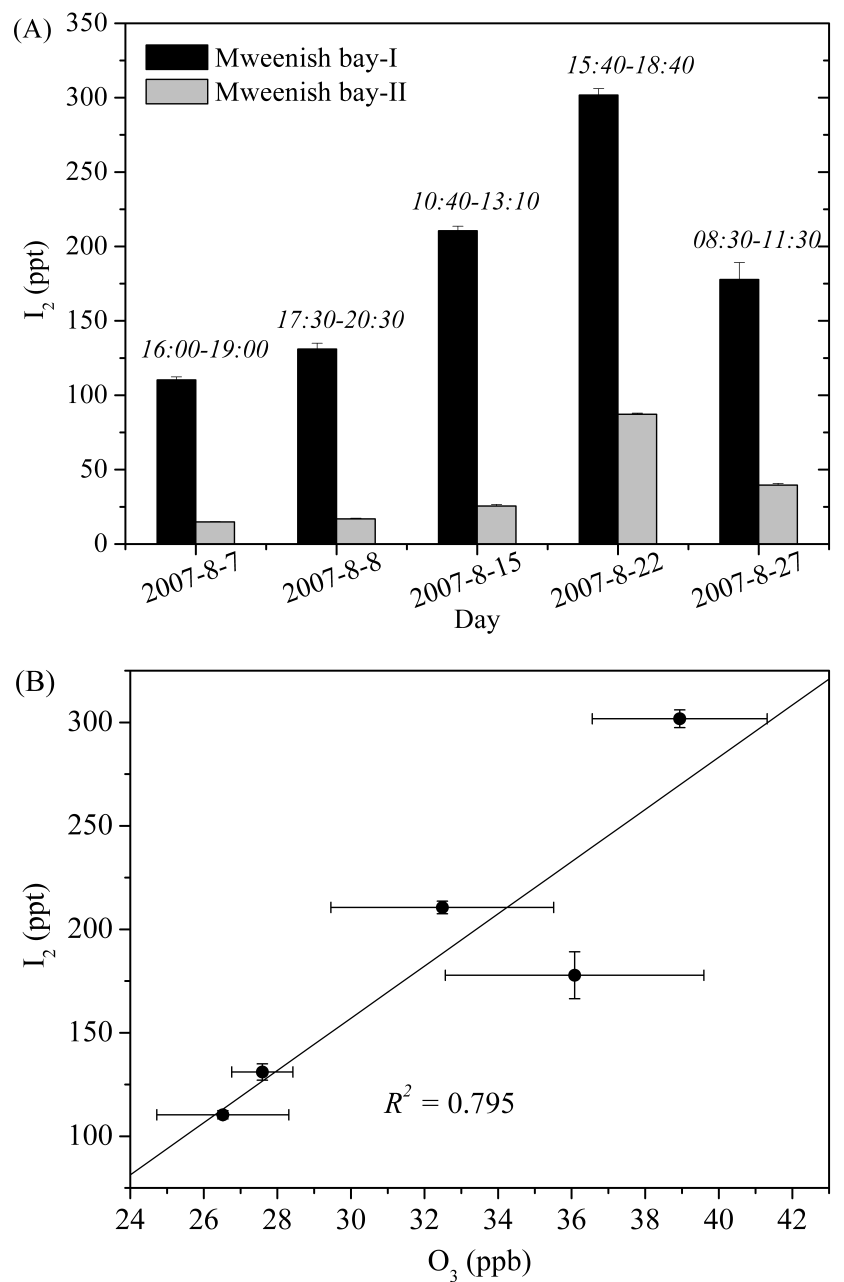

Fig. 2. Comparison of the mixing ratio of $I_{2}$ between Mweenish Bay-I and Mweenish Bay-II (A), and the correlation between the emission of $\mathrm{I}_{2}$ and $\mathrm{O}_{3}$ in the surrounding air at Mweenish Bay-I (B), measured directly above the algal beds.

northeasterly (land) direction the levels of $\mathrm{I}_{2}$ measured at Mweenish Bay-II decreased further to around $5 \mathrm{ppt}$, which indicates that local algae is the dominant emission source of $\mathrm{I}_{2}$ under the ambient conditions in the coastal area.

Over the course of this study the concentration levels of $\mathrm{I}_{2}$ observed at Mace Head were significantly lower than that at Mweenish Bay-II. The maximum mixing ratios for daytime and nighttime measurements at Mace Head were $29 \mathrm{ppt}$ and $141 \mathrm{ppt}$, respectively, and the values at Mweenish Bay-II were $87 \mathrm{ppt}$ and $193 \mathrm{ppt}$, respectively. The discrepancies of $\mathrm{I}_{2}$ levels between Mace Head and Mweenish Bay can be attributed to the higher biomass density at Mweenish Bay than at Mace Head and the difference on algae species composition present at these two locations (Irish Seaweed Centre, 2001). It suggests that the algae species Ascophyllum nodosum and Fucus vesiculosus at Mweenish Bay are strong $\mathrm{I}_{2}$ sources and that Mweenish Bay is a "hot spot" of iodine atmospheric chemistry.
Since algae are an important source of ambient $\mathrm{I}_{2}$ and the biomass of algae exposed to air is related to the tidal height, the tidal effects on $\mathrm{I}_{2}$ emissions were investigated during daytime and nighttime throughout the campaign at Mweenish Bay-II. A plot of $\mathrm{I}_{2}$ mixing ratio as a function of tide height exhibits a clear anticorrelation (Fig. 3), which is in agreement with the recent observations at Mace Head (Bale et al., 2008; Saiz-Lopez et al., 2006a). It is apparent that the levels of $\mathrm{I}_{2}$ are higher at low tide during nighttime due to its accumulation in the absence of solar photolysis. Nevertheless, we also observed that $\mathrm{I}_{2}$ mixing ratios at Mweenish Bay-II were maintained at levels of around 15-18 ppt even when strong westerly winds occurred ( $>10.8 \mathrm{~m} \mathrm{~s}^{-1}$, from sea direction), irrespective of the state of tide as well as day or night. Given that a certain amount of macroalgae at the nearby rocky upper littoral zone was still exposed to the atmosphere during high tide, these values (15-18 ppt) could represent the background level of $\mathrm{I}_{2}$ at the coastline.

The concentrations of reactive organic iodine species measured at Mace Head by an online GC-MS technique are compared to $\mathrm{I}_{2}$ observed by the denuder/GC-MS method in Fig. 4. Clearly, the concentration of $I_{2}$ is much higher than that of the iodocarbons for both daytime and nighttime measurements. Therefore, it is clear that $I_{2}$ is the predominant iodine precursor at Mace Head. However, like the emissions of $\mathrm{I}_{2}$, the biogenic emissions of iodocarbons are also algae species dependent, and high concentration levels of iodocarbons have been reported at Brittany, a French Atlantic Coast (Peters et al., 2005). Therefore, it is difficult to tell whether $\mathrm{I}_{2}$ is the predominant source of iodine in coastal areas other than Mace Head.

\subsection{Implications for $\mathrm{O}_{3}, \mathrm{IO}, \mathrm{OIO}$ and $\mathrm{NO}_{\mathrm{x}}$}

IO mixing ratios were measured by LP-DOAS at both Mweenish Bay and Mace Head during the campaign. The average and maximum values of daytime IO were $3.4 \pm 1.0$ and $9.5 \pm 0.8 \mathrm{ppt}$ for consecutive 30-day measurements at Mweenish Bay, and $1.1 \pm 0.3$ and $4.4 \pm 0.6 \mathrm{ppt}$ for consecutive 9-day measurements at Mace Head, respectively. Note that the maximum mixing ratios were observed around noon. A plot of three sets of data measured at Mweenish Bay indicates that daytime IO concentration levels increase with the increase of $I_{2}$ concentrations and of the solar irradiation, as shown in Fig. 5. A similar trend was also observed at Mace Head by Commane et al. (2008) during this campaign. These provide good evidence for the photochemical production of IO from coastal emissions of $\mathrm{I}_{2}$. Figure 5 also shows that $\mathrm{I}_{2}$ concentrations increase with enhanced solar irradiation. Since enhanced biological activity and biogenic emissions of iodine species have been suggested to correlate with solar irradiation together with warmer temperature (Carpenter et al., 1999), $\mathrm{I}_{2}$ emissions can be expected to be more elevated when low tide periods coincide with maximum solar irradiation exposure. 


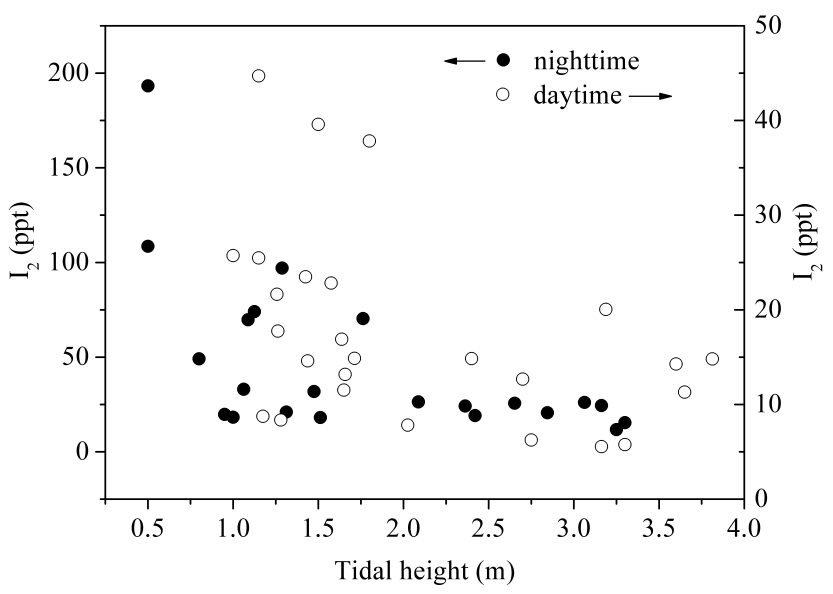

Fig. 3. The mixing ratio of $I_{2}$ as a function of tidal height at the sampling site Mweenish Bay-II.

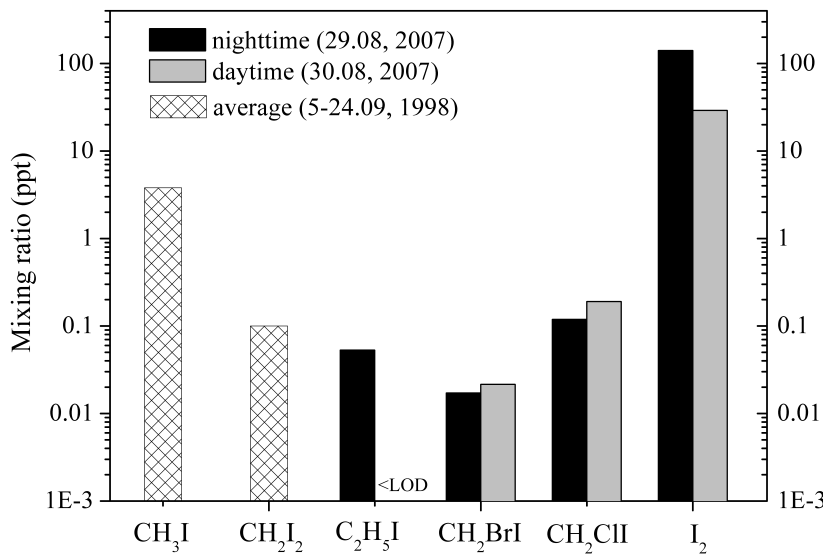

Fig. 4. Typical mixing ratios of reactive organic iodine species and $\mathrm{I}_{2}$ at Mace Head. The average $\mathrm{CH}_{3} \mathrm{I}$ and $\mathrm{CH}_{2} \mathrm{I}_{2}$ mixing ratios during the 1998 PARFORCE campaign at Mace Head (also given in Carpenter et al., 2003) are included since these two species were not measured during the campaign in 2007. The limits of detection (LODs) for $\mathrm{CH}_{3} \mathrm{I}, \mathrm{C}_{2} \mathrm{H}_{5} \mathrm{I}, \mathrm{CH}_{2} \mathrm{BrI}$ and $\mathrm{CH}_{2} \mathrm{ICl}$ are $0.2,0.1,0.02$ and $0.04 \mathrm{ppt}$, respectively. The bar is missing if the mixing ratio is below the LOD. Note the logarithmic scale.

Recent models predict that bromine- and iodine-induced ozone destruction can also occur in the troposphere (Vogt et al., 1999; von Glasow et al., 2004), and observations of $\mathrm{IO}$ and $\mathrm{BrO}$ have been linked to extensive halogen-mediated ozone destruction over the tropical Atlantic Ocean (Read et al., 2008). However, reduction in the tropospheric ozone burden through iodine emitted from coastal marine sources has not been verified by observations so far. During the 5week field observations at Mweenish Bay, the mixing ratio of ozone decreased in several days from the normal levels of $\sim 40 \mathrm{ppb}$ down to as low as $12 \mathrm{ppb}$. Since the measurements by denuders did not cover all these ozone destruction events observed by LP-DOAS and the time resolution of the

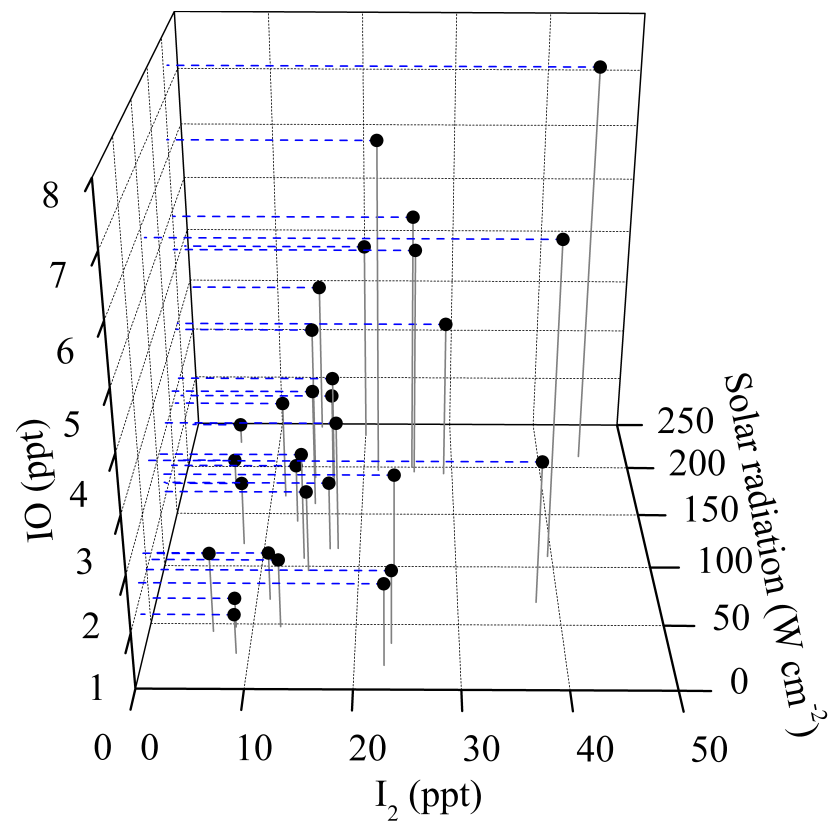

Fig. 5. Observed daytime IO mixing ratios as a function of solar radiation and $\mathrm{I}_{2}$. Measurements were taken at Mweenish Bay.

two techniques was different, we use the mean $\mathrm{O}_{3}$ concentrations observed at the timescales of $\mathrm{I}_{2}$ measurements to investigate the correlations between these two ambient constituents. The results show that the $\mathrm{O}_{3}$ concentration decreased in general with the increase of $\mathrm{I}_{2}$ concentration for daytime observations (Fig. 6), which is consistent with the observations shown in Fig. 5 and strongly supports the viewpoint that photochemical production of daytime IO is related to concentration levels of $\mathrm{O}_{3}$. For nighttime observations, a clear anti-correlation of $\mathrm{O}_{3}$ with $\mathrm{I}_{2}$ was observed, as shown in Fig. 6. Surprisingly, the $\mathrm{O}_{3}$ concentrations dropped significantly to around $15 \mathrm{ppb}$ when a high level of $\mathrm{I}_{2}$ mixing ratio was observed around midnight. Here, it should be noted that the correlation between $\mathrm{O}_{3}$ and $\mathrm{I}_{2}$ shown in Fig. 6 is opposite to that shown in Fig. 2b. This can be attributed to the difference in the sampling locations. The positive correlation presented in Fig. $2 \mathrm{~b}$ was measured directly above the algal beds, therefore, can be the consequence of the ozonescavenging reaction of iodide on the algae surfaces at low tide (i.e., $\mathrm{I}^{-}+\mathrm{O}_{3} \rightarrow \mathrm{I}_{2}$ ) (Küpper et al., 2008). However, the negative correlation presented in Fig. 6 was measured in the intertidal zone about $150 \mathrm{~m}$ from the algal beds. In this case, the emitted $\mathrm{I}_{2}$ will mix up and react with other atmospheric constituents, leading to the $\mathrm{O}_{3}$ destruction.

The chemistry of iodine at nighttime is still uncertain. The gas-phase reaction of $\mathrm{I}_{2}$ with $\mathrm{O}_{3}$ is too slow (Vikis and Macfarlane, 1985) to lead to significant $\mathrm{O}_{3}$ destruction. A suggested reaction (Chambers et al., 1992; Saiz-Lopez et al., 2006a) for the formation of atomic iodine (Reaction R1) at night is 


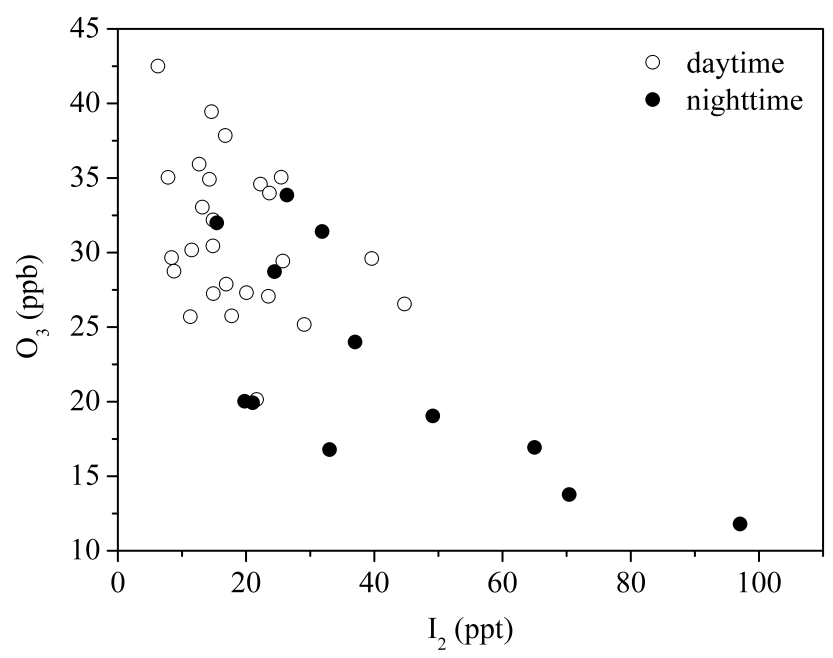

Fig. 6. Plot of $\mathrm{O}_{3}$ versus $\mathrm{I}_{2}$ during ozone destruction events at Mweenish Bay.

$\mathrm{I}_{2}+\mathrm{NO}_{3} \rightarrow \mathrm{I}+\mathrm{IONO}_{2}$

Based on quantum chemical calculations this reaction has recently been proposed to be the major source of iodine oxides at night (Kaltsoyannis and Plane, 2008). The resulting atomic iodine will then react rapidly with $\mathrm{O}_{3}$ to form IO (Reaction R2). The IO produced can react with $\mathrm{NO}_{3}$ (Reaction R3) with a rate coefficient of $9 \times 10^{-12} \mathrm{~cm}^{3}$ molecule ${ }^{-1} \mathrm{~s}^{-1}$ (Dillon et al., 2008), which will lead to additional $\mathrm{NO}_{3}$ consumption and will compete with $\mathrm{IO}+\mathrm{IO}$ for nighttime OIO formation.

$\mathrm{I}+\mathrm{O}_{3} \rightarrow \mathrm{IO}+\mathrm{O}_{2}$

$\mathrm{IO}+\mathrm{NO}_{3} \rightarrow \mathrm{OIO}+\mathrm{NO}_{2}$

Our observations during nighttime at Mweenish Bay show that, with the increase of $\mathrm{I}_{2}$ concentrations, the $\mathrm{NO}_{3}$ concentrations decrease (Fig. 7). The results indicate the importance of nitrate radicals for nighttime iodine chemistry in the coastal marine boundary layer (MBL). However, it should be noted that the lower $\mathrm{O}_{3}$ levels at higher $\mathrm{I}_{2}$ levels would also indicate a lower source of $\mathrm{NO}_{3}$ given the production pathway of $\mathrm{NO}_{3}$ (Reaction $\mathrm{R} 4$ ).

$\mathrm{NO}_{2}+\mathrm{O}_{3} \rightarrow \mathrm{NO}_{3}+\mathrm{O}_{2}$

It also should be noted that the observed $\mathrm{O}_{3}$ loss rate for both daytime and nighttime measurements (Fig. 6) is much higher than the value predicted by model simulations by Saiz-Lopez et al. (2006a, b). A possible explanation could be that other halogen compounds which have the similar diurnal pattern as $\mathrm{I}_{2}$ also contribute to the $\mathrm{O}_{3}$ loss. Indeed, the activated iodine compounds, $\mathrm{ICl}$ and HOI, showed a strong correlation with $\mathrm{I}_{2}$ (Huang and Hoffmann, 2009).

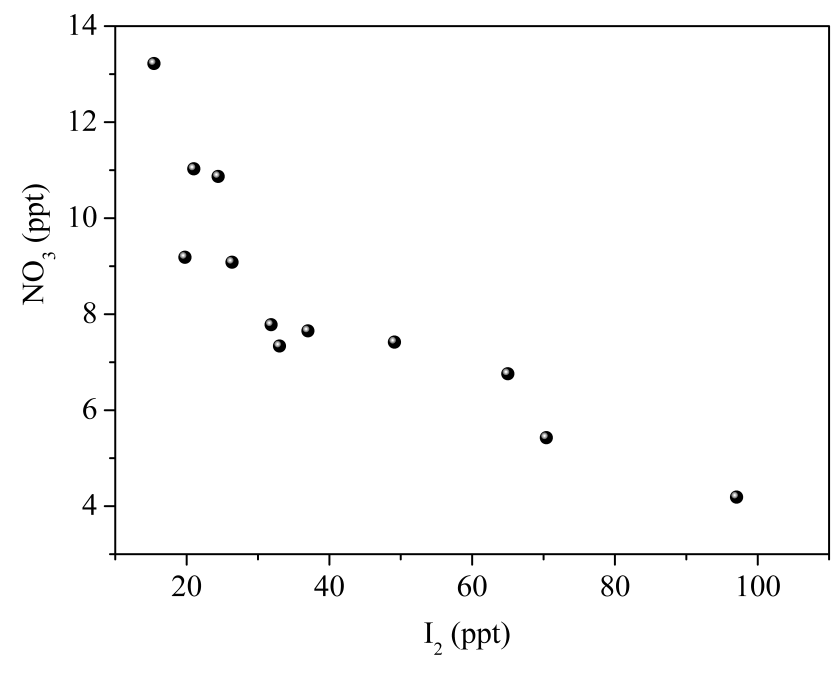

Fig. 7. $\mathrm{NO}_{3}$ as a function of $\mathrm{I}_{2}$ at night at Mweenish Bay.

During the campaign OIO was also measured at Mweenish Bay and Mace Head. Unambiguous identification of the absorption structure of OIO was not realized although it was observed several times above the detection limit (average, $12.5 \mathrm{ppt}$ at Mweenish Bay and 3.3 ppt at Mace Head, respectively). The measurement of OIO in the spectral region of 500-600 nm has some principal problems (Peters et al., 2005), leading to high residual structures and therefore high errors and high limit of detection. To date the only unambiguous daytime OIO measurements is made in the Gulf of Maine (Stutz et al., 2007). At Mace Head (Peters et al., 2005; Saiz-Lopez et al., 2006a), Cape Grim (Allan et al., 2001), and Roscoff (Mahajan et al., 2009), OIO has been observed during the nighttime but never in the daytime.

\subsection{Data evaluation}

Gas-phase reactive inorganic iodine species $\left(\mathrm{I}_{2}, \mathrm{IO}\right.$, and OIO) have been observed at Mace Head previously (Table 1). A maximum mixing ratio of $\mathrm{I}_{2}$ of $93 \mathrm{ppt}$ at night and $25 \mathrm{ppt}$ during the day was observed by LP-DOAS during the NAMBLEX campaign (Saiz-Lopez and Plane, 2004). In situ measurements of daytime $\mathrm{I}_{2}$ were also performed at Mace Head using BBCRDS (Bitter et al., 2005) and at a nearby location (Mweenish bridge) using denuder tubes in combination with ICP-MS analysis (Saiz-Lopez et al., 2006b), which reported much higher mixing ratios of daytime $\mathrm{I}_{2}$ compared to the LP-DOAS measurements (see Table 1). A more comprehensive comparison between "single-point" in situ and LPDOAS measurements was carried out at both Mace Head and Mweenish Bay during the campaign. Note that average values of LP-DOAS measurements within the same sampling period of denuder measurements at Mweenish Bay-II and Mace Head were used for comparison because of the different time resolution of the two techniques. As shown in 
Table 1. Observations of reactive inorganic iodine species ( $\mathrm{I}_{2}, \mathrm{IO}$, and $\left.\mathrm{OIO}\right)$ at Mace Head and Mweenish Bay, Ireland, by different techniques.

\begin{tabular}{|c|c|c|c|c|c|c|}
\hline \multirow{2}{*}{ Species } & \multirow{2}{*}{ Location, year } & \multirow{2}{*}{ Technique } & \multirow{2}{*}{ Spatiality } & \multicolumn{2}{|c|}{ Max. conc. (ppt) } & \multirow{2}{*}{ Reference } \\
\hline & & & & Daytime & Nighttime & \\
\hline \multirow[t]{9}{*}{$\mathrm{I}_{2}$} & Mace Head, 1998 & LP-DOAS & $14.4 \mathrm{~km}$ & - & $61.3 \pm 12$ & Peters et al. (2005) \\
\hline & Mace Head, 2002 & LP-DOAS & $8.4 \mathrm{~km}$ & 25 & $93 \pm 3$ & Saiz-Lopez and Plane (2004) \\
\hline & Mace Head, 2002 & BBCRDS & "point" in situ & $94 \pm 20$ & - & Bitter et al. (2005) \\
\hline & Mweenish bridge, 2003 & Denuder/ICP-MS & "point" in situ & 115 & - & Saiz-Lopez et al. (2006b) \\
\hline & Mace Head, 2007 & Denuder/GC-MS & "point" in situ & $29.1 \pm 1.0$ & $140.7 \pm 5.6$ & this work \\
\hline & Mace Head, 2007 & LP-DOAS & $13.6 \mathrm{~km}$ & - & 94.4 & this work \\
\hline & Mweenish Bay-I, 2007 & Denuder/GC-MS & "point" in situ & $301.8 \pm 4.3$ & - & this work \\
\hline & Mweenish Bay-II, 2007 & Denuder/GC-MS & "point" in situ & $87.2 \pm 1.8$ & $193.3 \pm 9.3$ & this work \\
\hline & Mweenish Bay, 2007 & LP-DOAS & $4.0 \mathrm{~km}$ & - & - & this work \\
\hline \multirow[t]{8}{*}{ IO } & Mace Head, 1997 & LP-DOAS & $14.4 \mathrm{~km}$ & $6.7 \pm 0.5$ & - & Alicke et al. (1999) \\
\hline & Mace Head, 1998 & LP-DOAS & $14.4 \mathrm{~km}$ & $7.2 \pm 0.3$ & - & Hebestreit (2001) \\
\hline & Mace Head, 2002 & LP-DOAS & $8.4 \mathrm{~km}$ & $7.0 \pm 0.5$ & 3 & Saiz-Lopez and Plane (2004) \\
\hline & Mace Head, 2007 & LIF & "point" in situ & $33.8 \pm 3.3$ & - & Commane et al. (2008) \\
\hline & Mace Head, 2007 & LP-DOAS & $13.6 \mathrm{~km}$ & $4.4 \pm 0.6$ & - & this work \\
\hline & Mweenish Bay, 2007 & LP-DOAS & $4.0 \mathrm{~km}$ & $9.5 \pm 0.8$ & - & this work \\
\hline & Mace Head, 1998 & LP-DOAS & $14.4 \mathrm{~km}$ & - & $9.2 \pm 3.3$ & Peters et al. (2005) \\
\hline & Mace Head, 2002 & LP-DOAS & $8.4 \mathrm{~km}$ & $<4$ & 10.8 & Saiz-Lopez et al. (2006a) \\
\hline \multirow{3}{*}{ OIO } & Mace Head, 2002 & BBCRDS & "point" in situ & - & $13 \pm 4$ & Bitter et al. (2005) \\
\hline & Mace Head, 2007 & LP-DOAS & $13.6 \mathrm{~km}$ & - & - & this work \\
\hline & Mweenish Bay & LP-DOAS & $4.0 \mathrm{~km}$ & - & - & this work \\
\hline
\end{tabular}

Fig. 8, the denuder method recorded much higher concentrations of $I_{2}$ than the LP-DOAS method, for both daytime and nighttime measurements. This can be attributed to the facts that denuder method provides "single-point" measurements in the intertidal zone, whereas the LP-DOAS technique provides distance-averaged mixing ratios of a rather inhomogeneous distribution along the light-path (i.e., 4-14 km). As described above, the local algal sources dominate the inorganic iodine chemistry at Mace Head and Mweenish Bay. However, under the conditions of Mace Head and Mweenish Bay, the seaweeds extend only over a short distance of the DOAS light-path and most of the light-path extended over the open sea. In addition, a vertical $I_{2}$ concentration gradient caused by its rapid photolysis during daytime and by diffusion at night is expected. The vertical distance between the denuder inlets and the sea level is shorter than that between the DOAS light-path and sea level. Thus, the inhomogeneous spatial distribution of $\mathrm{I}_{2}$ can be responsible for the observed discrepancies of $\mathrm{I}_{2}$ mixing ratios.

The maximum mixing ratios of daytime IO measured by LP-DOAS at Mace Head are consistent with previous observations. However, the levels observed at Mweenish Bay are significantly higher than that at Mace Head. These results suggest that Mweenish Bay is a biological "hot spot" of iodine atmospheric chemistry. It should be noted that LPDOAS averages over a few kilometers and the time resolution of denuder sampling is greater than tens of minutes.

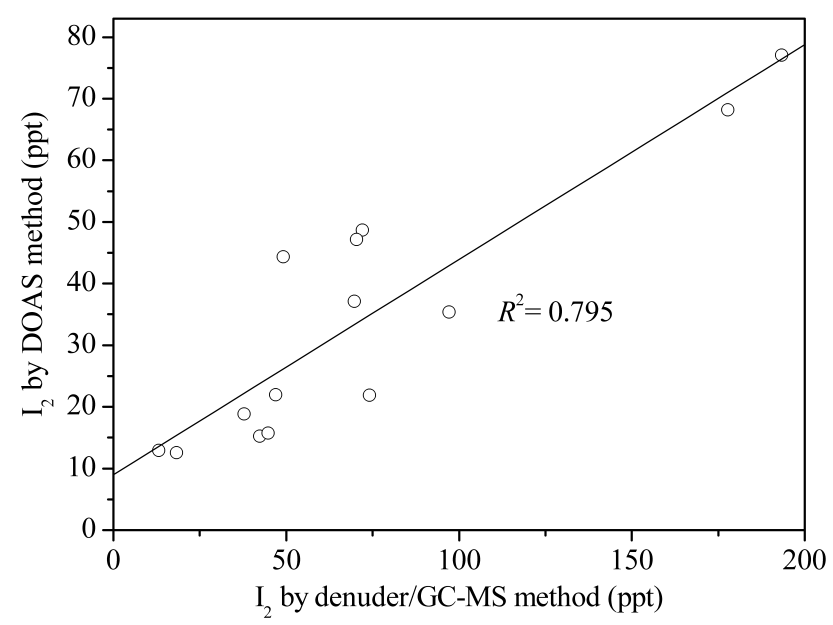

Fig. 8. Comparison of $I_{2}$ mixing ratios measured by denuder/GCMS and LP-DOAS.

This does not allow measurements at the spatial and temporal scales at which the iodine species $\left(\mathrm{I}_{2}, \mathrm{IO}\right.$, and $\left.\mathrm{OIO}\right)$ are produced. Therefore, it can be expected that the actual peak values of these three iodine species could be higher than those reported here. This is supported by comparison results of IO measurements by LP-DOAS and laser-induced fluorescence (LIF) spectroscopy at Mace Head (Commane et al., 2008). Since the LIF technique provides "point" in situ measurements with a very high time resolution ( $10 \mathrm{~s}-5 \mathrm{~min})$, 
the maximum mixing ratios of IO observed by LIF are significantly higher than that measured by LP-DOAS, with a maximum value of $34 \mathrm{ppt}$ reported. Considering the limit of detection of the denuder/GC-MS method $(0.17 \mathrm{ppt}$ for a sampling duration of $30 \mathrm{~min}$ at $500 \mathrm{~mL} \mathrm{~min}^{-1}$ ) as well as the concentration levels at the west coast of Ireland, we suggest a shorter sampling time for example 10-30 min for further field measurements in algae-rich coastal areas. This would allow a more detailed study of the diurnal variation of ambient $I_{2}$ and a better understanding of the release mechanisms and atmospheric impact of $\mathrm{I}_{2}$.

\section{Summary}

A diffusion denuder in combination with a GC-MS method has been used for "single-point" in situ measurements of $\mathrm{I}_{2}$ at the West Coast of Ireland. The observations show that above algal beds, the emissions of $\mathrm{I}_{2}$ from macroalgae are correlated with the surrounding $\mathrm{O}_{3}$ concentration levels. Comparison of $\mathrm{I}_{2}$ measurements was carried out at Mace Head and Mweenish Bay, and the results indicate that the mixing ratios of $I_{2}$ are correlated with species and biomass of local algae and that Mweenish Bay is a biological "hot spot" of iodine atmospheric chemistry. An anticorrelation between $I_{2}$ concentration levels and tidal height was observed for both daytime and nighttime measurements. In addition, the mixing ratios of $\mathrm{I}_{2}$ were also measured by LP-DOAS and compared to the denuder/GC-MS measurements. The results show that local coastal emissions are the main source of ambient $I_{2}$ and that the denuder/GC-MS method can be used to better identify the potential source of $\mathrm{I}_{2}$.

Measurements made $\sim 150 \mathrm{~m}$ away from the algal beds showed a negative correlation between $\mathrm{O}_{3}$ and $\mathrm{I}_{2}$ during both day and night. The levels of $I_{2}$ and the intensity of solar irradiation significantly effect the mixing ratios of daytime $\mathrm{IO}$ and consequently the potential for $\mathrm{O}_{3}$ destruction. During nighttime, the involvement of $\mathrm{NO}_{\mathrm{x}}$ in the reaction cycles of $\mathrm{I}_{2}$ is suggested to be responsible for the enhanced $\mathrm{O}_{3}$ destruction. Further laboratory-based studies and field measurements are required to clarify the importance of the nighttime atmospheric chemistry of iodine.

Acknowledgements. This work was supported by the European Union under the FP6 project (Contract No. 018332): Marine Aerosol Production (MAP), the German Research Foundation (Deutsche Forschungsgemeinschaft, DFG) within the graduate program 826 "Trace Analysis of Elemental Species: Development of Methods and Applications", the European Science Foundation INTROP exchange scheme and the European Community EUSAAR Infrastructure fund, as well as NERC grant NE/D006538/1. The authors are grateful to Colin O'Dowd (NUI, Galway) for leading the field campaign and to the Martin Ryan Institute, especially Richard Fitzgerald, for the support during the field measurements. KEH acknowledges NERC for award of a studentship.

Edited by: A. Pszenny

\section{References}

Alicke, B., Hebestreit, K., Stutz, J., and Platt, U.: Iodine oxide in the marine boundary layer, Nature, 397, 572-573, 1999.

Allan, B. J., Plane, J. M. C., and McFiggans, G.: Observations of OIO in the remote marine boundary layer, Geophys. Res. Lett. 28, 1945-1948, 2001.

Bale, C. S. E., Ingham, T., Commane, R., Head, D. E., and Bloss, W. J.: Novel measurements of atmospheric iodine species by resonance fluorescence, J. Atmos. Chem., 60, 51-70, 2008.

Bitter, M., Ball, S. M., Povey, I. M., and Jones, R. L.: A broadband cavity ringdown spectrometer for in-situ measurements of atmospheric trace gases, Atmos. Chem. Phys., 5, 2547-2560, doi:10.5194/acp-5-2547-2005, 2005.

Bloss, W. J., Rowley, D. M., Cox, R. A., and Jones, R. L.: Kinetics and products of the IO self-reaction, J. Phys. Chem. A, 105, 7840-7854, 2001.

Carpenter, L. J.: Iodine in the marine boundary layer, Chem. Rev., 103, 4953-4962, 2003.

Carpenter, L. J., Hebestreit, K., Platt, U., and Liss, P. S.: Coastal zone production of IO precursors: a 2-dimensional study, Atmos. Chem. Phys., 1, 9-18, doi:10.5194/acp-1-9-2001, 2001.

Carpenter, L. J., Liss, P. S., and Penkett, S. A.: Marine organohalogens in the atmosphere over the Atlantic and Southern Oceans, J. Geophys. Res., 108(D9), 4256, doi:10.1029/2002JD002769, 2003.

Carpenter, L. J., Sturges, W. T., Penkett, S. A., Liss, P. S., Alicke, B., Hebestreit, K., and Platt, U.: Short-lived alkyl iodides and bromides at Mace Head, Ireland: Links to biogenic sources and halogen oxide production, J. Geophys. Res.-Atmos, 104, 16791689, 1999.

Chambers, R. M., Heard, A. C., and Wayne, R. P.: Inorganic gasphase reactions of the nitrate radical: $\mathrm{I}_{2}+\mathrm{NO}_{3}$ and $\mathrm{I}+\mathrm{NO}_{3}, \mathrm{~J}$. Phys. Chem., 96, 3321-3331, 1992.

Commane, R., Bale, C. S. E., Furneaux, K. L., Ingham, T., Whalley, L. K., Heard, D. E., and Bloss, W. J.: Iodine monoxide in the marine boundary layer, EGU General Assembly, Vienna, Austria, 13-18 April 2008, EGU2008-A-04243, 2008.

Dixneuf, S., Ruth, A. A., Vaughan, S., Varma, R. M., and Orphal, J.: The time dependence of molecular iodine emission from Laminaria digitata, Atmos. Chem. Phys., 9, 823-829, doi:10.5194/acp-9-823-2009, 2009.

Dillon, T. J., Tucceri, M. E., Sander, R., and Crowley, J. N.: LIF studies of iodine oxide chemistry, Part 3. Reactions $\mathrm{IO}+\mathrm{NO}_{3} \rightarrow$ $\mathrm{OIO}+\mathrm{NO}_{2}, \mathrm{I}+\mathrm{NO}_{3} \rightarrow \mathrm{IO}+\mathrm{NO}_{2}$, and $\mathrm{CH}_{2} \mathrm{I}+\mathrm{O}_{2} \rightarrow$ (products): implications for the chemistry of the marine atmosphere at night, Phys. Chem. Chem. Phys., 10, 1540-1554, 2008.

Greenblatt, G. D., Orlando, J. J., Burkholder, J. B., and Ravishankara, A. R.: Absorption-measurements of oxygen between $330 \mathrm{~nm}$ and $1140 \mathrm{~nm}$, J. Geophys. Res.-Atmos., 95, 1857718582, 1990.

Hebestreit, K.: Halogen oxides in the mid-latitudinal planetary boundary layer, Institute for Umweltphysik, University of Heidelberg, PhD thesis, 2001.

Hoffmann, T., O'Dowd, C. D., and Seinfeld, J. H.: Iodine oxide homogeneous nucleation: An explanation for coastal new particle production, Geophys. Res. Lett., 28, 1949-1952, 2001.

Hornsby, K. E., Flynn, M. J., Dorsey, J. R., Gallagher, M. W., Chance, R., Jones, C. E., and Carpenter, L. J.: A Relaxed Eddy Accumulation (REA)-GC/MS system for the determina- 
tion of halocarbon fluxes, Atmos. Meas. Tech., 2, 437-448, doi:10.5194/amt-2-437-2009, 2009.

Huang, R.-J. and Hoffmann, T.: Development of a coupled diffusion denuder system combined with gas chromatography/mass spectrometry for the separation and quantification of molecular iodine and the activated iodine compounds iodine monochloride and hypoiodous acid in the marine atmosphere, Anal. Chem., 81, 1777-1783, 2009.

Huang, R.-J., Seitz, K., Neary, T., O’Dowd, C. D., Platt, U., and Hoffmann, T.: Observations of high concentrations of $\mathrm{I}_{2}$ and IO in coastal air supporting iodine-oxide driven coastal new particle formation, Geophys. Res. Lett., 37, L03803, doi:10.1029/2009GL041467, 2010.

Irish Seaweed Centre: Connemara seaweed survey, an assessment of the commercially valuable seaweed species of connemara, National University of Ireland, Galway, 1-44, 2001.

Kaltsoyannis, N. and Plane, J. M. C.: Quantum chemical calculations on a selection of iodine-containing species (IO, OIO, $\mathrm{INO}_{3}$, $(\mathrm{IO})_{2}, \mathrm{I}_{2} \mathrm{O}_{3}, \mathrm{I}_{2} \mathrm{O}_{4}$ and $\mathrm{I}_{2} \mathrm{O}_{5}$ ) of importance in the atmosphere, Phys. Chem. Chem. Phys., 10, 1723-1733, 2008.

Kraus, S.: DOASIS - a framework design for DOAS, Combined Faculties for Mathematics and for Computer Science, University of Mannheim, PhD thesis, 2005.

Küpper, F. C., Carpenter, L. J., McFiggans, G. B., Palmer, C. J., Waite, T. J., Boneberg, E. M., Woitsch, S., Weiller, M., Abela, R., Grolimund, D., Potin, P., Butler, A., Luther, G. W., Kroneck, P. M. H., Meyer-Klaucke, W., and Feiters, M. C.: Iodide accumulation provides kelp with an inorganic antioxidant impacting atmospheric chemistry, Proc. Natl. Acad. Sci. USA, 105, 69546958, 2008.

Küpper, F. C., Schweigert, N., Ar Gall, E., Legendre, J. M., Vilter, H., and Kloareg, B.: Iodine uptake in Laminariales involves extracellular, haloperoxidase-mediated oxidation of iodide, Planta, 207, 163-171, 1998.

Mahajan, A. S., Oetjen, H., Saiz-Lopez, A., Lee, J. D., McFiggans, G. B., Plane, J. M. C.: Reactive iodine species in a semi-polluted environment, Geophys. Res. Lett., 36, L16803, doi:10.1029/2009GL038018, 2009.

McFiggans, G., Coe, H., Burgess, R., Allan, J., Cubison, M., Alfarra, M. R., Saunders, R., Saiz-Lopez, A., Plane, J. M. C., Wevill, D., Carpenter, L., Rickard, A. R., and Monks, P. S.: Direct evidence for coastal iodine particles from Laminaria macroalgae - linkage to emissions of molecular iodine, Atmos. Chem. Phys., 4, 701-713, doi:10.5194/acp-4-701-2004, 2004.

Meller, R. and Moortgat, G. K.: Temperature dependence of the absorbtion cross section of formaldehyde between 223 and 323 $\mathrm{K}$ in the wavelength range $225-375 \mathrm{~nm}$, J. Geophys. Res., 105, 7089-7101, 2000.

O'Dowd, C. D. and Hoffmann, T.: Coastal new particle formation: a review of the current state-of-the-art, Environ. Chem., 2, 245255,2005

O’Dowd, C. D., Jimenez, J. L., Bahreini, R., Flagan, R. C., Seinfeld, J. H., Hämeri, K., Pirjola, L., Kulmala, M., Jennings, S. G., and Hoffmann, T.: Marine aerosol formation from biogenic iodine emissions, Nature, 417, 632-636, 2002.

Palmer, C. J., Anders, T. L., Carpenter, L. J., Küpper, F. C., and McFiggans, G. B.: Iodine and halocarbon response of Laminaria digitata to oxidative stress and links to atmospheric new particle production, Environ. Chem., 2, 282-290, 2005.
Peters, C., Pechtl, S., Stutz, J., Hebestreit, K., Hönninger, G., Heumann, K. G., Schwarz, A., Winterlik, J., and Platt, U.: Reactive and organic halogen species in three different European coastal environments, Atmos. Chem. Phys., 5, 3357-3375, doi:10.5194/acp-5-3357-2005, 2005.

Pirjola, L., O’Dowd, C. D., Yoon, Y. J., and Sellegri, K.: Modelling iodine particle formation and growth from seaweed in a chamber, Enivron. Chem., 2, 271-281, 2005.

Platt, U. and Stutz, J. (eds.): Differential optical absorption spectroscopy: Principles and applications, in: Physics of earth and space environments, Springer-Verlag Berlin Heidelberg, 2008.

Read, K. A., Mahajan, A. S., Carpenter, L. J., Evans, M. J., Faria, B. V. E., Heard, D. E., Hopkins, J. R., Lee, J. D., Moller, S. J., Lewis, A. C., Mendes, L., McQuaid, J. B., Oetjen, H., SaizLopez, A., Pilling, M. J., and Plane, J. M. C.: Extensive halogenmediated ozone destruction over the tropical Atlantic Ocean, Nature, 453, 1232-1235, 2008.

Rothman, L. S., Jacquemart, D., Barbe, A., Benner, D. C., Birk, M., Brown, L. R., Carleer, M. R., Chackerian, C. J., Chance, K., Coudert, L. H., Dana, V., Devi, V. M., Flaud, J. M., Gamache, R. R., Goldman, A., Hartmann, J. M., Jucks, K. W., Maki, A. G., Mandin, J. Y., Massie, S. T., Orphal, J., Perrin, A., Rinsland, C. P., Smith, M. A. H., Tennyson, J., Tolchenov, R. N., Toth, R. A., Auwera, J. V., Varanasi, P., and Wagner, G.: The HITRAN 2004 molecular spectroscopic database, J. Quant. Spectrosc. Ra., 96, 139-204, 2005.

Saiz-Lopez, A., Mahajan, A. S., Salmon, R. A., Bauguitte, S. J.-B., Jones, A. E., Roscoe, H. K., and Plane, J. M. C.: Boundary layer halogens in coastal antarctica, Science, 317, 348-351, 2007.

Saiz-Lopez, A. and Plane, J. M. C.: Novel iodine chemistry in the marine boundary layer, Geophys. Res. Lett., 31, L04112, doi:10.1029/2003GL019215, 2004.

Saiz-Lopez, A., Plane, J. M. C., McFiggans, G., Williams, P. I., Ball, S. M., Bitter, M., Jones, R. L., Hongwei, C., and Hoffmann, T.: Modelling molecular iodine emissions in a coastal marine environment: the link to new particle formation, Atmos. Chem. Phys., 6, 883-895, doi:10.5194/acp-6-883-2006, 2006.

Saiz-Lopez, A., Saunders, R. W., Joseph, D. M., Ashworth, S. H., and Plane, J. M. C.: Absolute absorption cross-section and photolysis rate of I2, Atmos. Chem. Phys., 4, 1443-1450, doi:10.5194/acp-4-1443-2004, 2004.

Saiz-Lopez, A., Shillito, J. A., Coe, H., and Plane, J. M. C.: Measurements and modelling of $\mathrm{I}_{2}, \mathrm{IO}, \mathrm{OIO}, \mathrm{BrO}$ and $\mathrm{NO}_{3}$ in the mid-latitude marine boundary layer, Atmos. Chem. Phys., 6, 1513-1528, doi:10.5194/acp-6-1513-2006, 2006.

Seitz, K., Buxmann, J., Pöhler, D., Sommer, T., Tschritter, J., Neary, T., O'Dowd, C., and Platt, U.: The spatial distribution of the reactive iodine species $\mathrm{IO}$ from simultaneous active and passive DOAS observations, Atmos. Chem. Phys., 10, 2117-2128, doi:10.5194/acp-10-2117-2010, 2010.

Sellegri, K., Yoon, Y. J., Jennings, S. G., O’Dowd, C. D., Pirjola, L., Cautenet, S., Chen, H., and Hoffmann, T.: Quantification of coastal new ultra-fine particles formation from in situ and chamber measurements during the BIOFLUX campaign, Environ. Chem., 2, 260-270, 2005.

Spietz, P., Martin, J. C. G., and Burrows, J. P.: Spectroscopic studies of the $\mathrm{I}_{2} / \mathrm{O}_{3}$ photochemistry: Part 2. Improved spectra of iodine oxides and analysis of the IO absorption spectrum, J. Photoch. Photobio. A, 176, 50-67, 2005. 
Stutz, J., Kim, E. S., Platt, U., Bruno, P., Perrino, C., and Febo, A.: UV-visible absorption cross section of nitrous acid, J. Geophys. Res., 105, 14585-14592, 2000.

Stutz, J., Pikelnaya, O., Hurlock, S. C., Trick, S., Pechtl, S., and von Glasow, R.: Daytime OIO in the Gulf of Maine, Geophys. Res. Lett., 34, L22816, doi:10.1029/2007GL031332, 2007.

Stutz, J. and Platt, U.: Numerical analysis and estimation of the statistical error of differential optical absorption spectroscopy measurements with least-squares methods, Appl. Optics, 35, 60416053, 1996.

Vaughan, S., Gherman, T., Ruth, A. A., and Orphal, J.: Incoherent broad-band cavity-enhanced absorption spectroscopy of the marine boundary layer species $\mathrm{I}_{2}, \mathrm{IO}$ and OIO, Phys. Chem. Chem. Phys., 10, 4471-4477, 2008.

Vandaele, A. C., Simon, P. C., Guilmot, J. M., Carleer, M., and Colin, R.: $\mathrm{SO}_{2}$ absorption cross-section measurement in the UV using a fourier-transform spectrometer, J. Geophys. Res.-Atmos., 99, 25599-25605, 1994.

Vikis, A. C. and MacFarlane, R.: Reaction of iodine with ozone in the gas phase, J. Phys. Chem., 89, 812-815, 1985.

Vogt, R., Sander, R., von Glasow, R., and Crutzen, P. J.: Iodine chemistry and its role in halogen activation and ozone loss in the marine boundary layer: A model study, J. Atmos. Chem., 32, 375-395, 1999.

Voigt, S., Orphal, J., Bogumil, K., and Burrows, J. P.: The temperature dependence (203-293 K) of the absorption cross sections of $\mathrm{O}_{3}$ in the $230-850 \mathrm{~nm}$ region measured by Fourier-transform spectroscopy, J. Photoch. Photobio. A, 143, 1-9, 2001.
Voigt, S., Orphal, J., and Burrows, J. P.: The temperature and pressure dependence of the absorption cross-sections of $\mathrm{NO}_{2}$ in the $250-800 \mathrm{~nm}$ region measured by Fourier-transform spectroscopy, J. Photoch. Photobio. A, 149, 1-7, 2002.

von Glasow, R. and Crutzen, P. J.: Tropospheric halogen chemistry, in: Treatise on Geochemistry Update 1, edited by: Holland, H. D. and Turekian, K. K., Eleviser, Amsterdam, The Netherlands, Vol. 4.02, 1-67, 2007.

von Glasow, R., von Kuhlmann, R., Lawrence, M. G., Platt, U., and Crutzen, P. J.: Impact of reactive bromine chemistry in the troposphere, Atmos. Chem. Phys., 4, 2481-2497, doi:10.5194/acp4-2481-2004, 2004.

Wevill, D. J. and Carpenter, L. J.: Automated measurement and calibration of reactive volatile halogenated organic compounds in the atmosphere, Analyst, 129, 634-638, 2004.

Wilmouth, D. M., Hanisco, T. F., Donahue, N. M., and Anderson, J. G.: Fourier transform untraviolet spectroscopy of the A ${ }^{2} \Pi_{3 / 2} \leftarrow \mathrm{X}^{2} \Pi_{3 / 2}$ transition of BrO, J. Phys. Chem. A, 103, 8935-8945, 1999.

Yokelson, R. J., Burkholder, J. B., Fox, R. W., Talukdar, R. K., and Ravishankara, A. R.: Temperature dependence of the $\mathrm{NO}_{3}$ absorption spectrum, J. Phys. Chem. 98, 13144-13150, 1994. 